\title{
Komparasi Hukum Acara Pembuktian E-Arbitration di Indonesia dengan Shenzhen, Cina
}

\author{
I Gusti Agung Ayu Gita Pritayanti Dinar ${ }^{1}$
}

${ }^{1}$ Fakultas Hukum Universitas Warmadewa, E-mail: gitadinar@gmail.com

\begin{tabular}{l}
\hline Info Artikel \\
\hline Masuk: 25 November 2020 \\
Diterima: 25 November 2020 \\
Terbit: 6 Januari 2020 \\
Keywords: \\
Legal protection; Evidence \\
collection procedure, - - \\
arbitration \\
\\
\\
Kata kunci: \\
Perlindungan Hukum, Acara \\
Pembuktian, e-arbitrase \\
Corresponding Author: \\
I Gusti Agung Ayu Gita \\
Pritayanti Dinar, E-mail: \\
gitadinar@gmail.com \\
DOI: \\
10.24843/AC.2020.v05.i03.p17
\end{tabular}

\begin{abstract}
Online dispute resolution (ODR) is designed to facilitate the proceedings of parties dispute through online technology media such as PCSs, laptops and cell-phones. ODR is expected to facilitate an effective mediation, adjudication communication, so it can provide benefits in the form of time and cost efficiency in dispute resolution. The research questions investigated in this study are: (i) What are the advantages of the concept of proceedings by e-arbitration? (ii) Does the e-arbitration evidence collection procedure in accordance with the evidence principles of civil procedure law? This study employs the normative legal research method. The theories applied in investigating the problems in this research are the economic-legal theory and evidence principles. Through this study, it can be determined the comparison of procedure, benefit of e-arbitration evidence regulation in ShenZhen and Indonesia.
\end{abstract}

\section{Pendahuluan}

Teknologi yang tidak pernah ketinggalan mode dan tren, selalu menyesuaikan perkembangan kebutuhan masyarakat bahkan berkembang terlalu pesat sehingga terkadang terjadi ketimpangan antara negara maju yang sudah sangat mapan dengan 
kebutuhan teknologi jika dibandingkan beberapa negara berkembang yang masih sangat tradisional dan cenderung kurang mengenal cara memanfaatkan teknologi dan internet. Technology"is now pervasive in our world. Consider the number of users of mobile phones (5 bilion), the internet (3,5 bilion) of email. One key challenge for the legal professions, however is to adopt new systems earlier and to identify and grasp the opportunities afforded by emerging"technologies. ${ }^{I}$ Sistem administrasi pengadilan di Indonesia turut menyambut baik kemajuan teknologi melalui sosialisasi e-court yang sudah diterapkan pada beberapa daerah, melalui Peraturan Mahkamah Agung Republik Indonesia Nomor 3 Tahun 2018 tentang administrasi perkara pengadilan secara elektronik. Penyelesaian sengketa komersial dapat diselesaikan melalui $e$-court dan e-arbitration. The challenge is to merge characteristics such as "due process," a "level playing field," and "neutral adjudication" (the best of the state court system) with the flexibility, informality, and responsiveness to the needs of the parties (the best of the ADR system), and so to create a paradigm of dispute resolution that meets the needs of e-commerce. ${ }^{2}$ Jika dibandingkan dengan penyelesaian sengketa di luar pengadilan lainnya seperti negosiasi, konsiliasi dan mediasi maka arbitrase adalah metode penyelesaian sengketa yang paling formal dan bonafide, karena sudah memiliki lembaga dan prosedur peraturan pelaksanaan tersendiri baik secara nasional dan internasional. A specific objective of the E-Arbitration-T project was to produce an online process that could be used by many different arbitration service providers to efficiently handle low value cases and be readily accessible to Small and Medium Scale Enterprises (SMEs). Since such users might not be familiar with the details of a given organisation's arbitration process this demanded that the system give correct procedural guidance. Thus it should be flexible. ${ }^{3}$ Proses peradilan bertujuan untuk memberikan solusi yang seadil-adilnya dan mempermudah proses penyelesaian sengketa yang terjadi diantara para pihak yang sedang mencari keadilan, ODR melalui e-arbitration dan e-court adalah beberapa metode dalam mempermudah prosedur tradisional yang telah disempurnakan dengan sistem administrasi beracara secara online. Problem terhadap norma yang mengatur pembuktian e-arbitration berdampak sangat besar terhadap kepastian hukum bagi para pencari keadilan khususnya para pelaku bisnis di Indonesia dan umumnya pelaku bisnis internasional yang cenderung memilih arbitrase sebagai badan alternatif untuk penyelesaian sengketa bisnis. Pembuktian secara online untuk sengketa lintas negara bisa saja lebih efisien dibandingkan jika para pihak harus hadir secara offline di ruang sidang, namun pembuktian ini haruslah memenuhi rasa keadilan bagi para pihak. Terkait dengan tidak adanya kejelasan mengenai lingkup ini maka ditemukan adanya kekosongan norma dalam pengaturan hukum acara pembuktian e-arbitration.

Rumusan masalah dalam penelitian ini 1) Apakah keunggulan konsep beracara secara $e$ arbitration? 2) Bagaimanakah komparasi hukum pembuktian e-arbitration di Indonesia dan di Shenzhen, Cina?. Tujuan umum dari penelitian ini adalah untuk melakukan perbandingan terhadap pengaturan hukum acara pembuktian e-arbitration Indonesia dengan Shenzhen, Cina. dalam penyelesaian sengketa bisnis melalui arbitrase internasional sehingga nantinya penelitian ini akan bermanfaat untuk menentukan

\footnotetext{
1 Susskind,R, (2017), Tomorrow's Lawyers: An Introduction to Your Future, Oxford University Press, Great Britain, p.3.

2 Gibbons.L.J, (2000), Private Law, Public "Justice": Another Look at Privacy, Arbitration, and Global E-Commerce, Ohio State Journal On Dispute Resolution, Vol 15:3, p. 770

${ }^{3}$ Elliman.T, Eatock.J, (2005), Onlinessupport For Arbitration: Designing Software For A Flexible Business Process, Int. J. Information Technology and Management, Vol. 4, No. 4, p. 444
} 
kompetensi keputusan yang adil, sedangkan yang menjadi tujuan khusus dari penelitian ini adalah untuk melakukan Analisa mengenai keunggulan konsep beracara secara $e$ arbitration dan untuk melakukan analisa mengenai prosedur pembuktian e-arbitration telah sesuai dengan asas-asas pembuktian dalam hukum acara perdata di Indonesia.

Dalam disertasi Sefriani yang berjudul Pelaksanaan Putusan Arbitrase Komersial Internasional Terkait Imunitas Aset Negara, ditemukan persamaan dan perbedaan dalam praktek negara-negara. Persamaannya adalah bahwa semua negara memisahkan antara jurisdictional immunity dengan enforcement immunity dan memiliki UU AKI. Perbedaannya adalah ada negara yg menerapkan imunitas. Disertasi ini bermanfaat untuk mengetahui praktek dari putusan arbitrase asing. ${ }^{4}$ Djunyanto Triyana menulis disertasi dengan judul Arbitrase Online Sebagai Metode Penyelesaian Sengketa Kredit Bermasalah Dihubungan Dengan Prinsip Itikad Baik Dalam Rangka Mendukung Perbankan Yang Sehat. Hasil dari penelitian ini bahwa pemikiran metode arbitrase online untuk lingkungan perbankan, menetaskan konsep arbitrase online berbasis itikad baik. Prinsip itikad baik dalam konsep ini berlandaskan konsep categorical imperative dari Immanuel Kant. Landasan filosofis konsep ini menghendaki pelaksanaan sukarela dalam menjalankan putusan majelis arbitrase berdasarkan kewajiban yang bersifat mengharuskan dan otonom, yakni muncul kesadaran sendiri tanpa dipengaruhi faktor eksternal. 5

\section{Metode Penelitian}

Penelitian ini menggunakan metode penelitian hukum normatif, penelitian hukum normatif berfungsi untuk memberi argumentasi yuridis ketika terjadi kekosongan, kekaburan dan konflik norma. Adapun pendekatan yang digunakan dalam penelitian ini yaitu (i) pendekatan analisa konsep (analitical and conceptual approach) yaitu segala permasalahan ditelaah berdasarkan konsep, teori, asas-asas, dan peraturan perundangundangan yang berlaku, (ii) Pendekatan perundang-undangan (the statue approach) yaitu dengan meneliti, membandingkan dan menganalisa BANI Arbitration Procedures dan Shenzhen Court Inernational Online Arbitration Rule, Peraturan Mahkamah Agung Republik Indonesia Nomor 3 Tahun 2018 tentang administrasi perkara pengadilan secara elektronik, serta peraturan perundang-undangan terkait dengan permasalahan, dan (iii) Pendekatan perbandingan (comparative approach) pendekatan ini dilakukan dengan mengadakan studi perbandingan hukum suatu negara tertentu dengan negaranegara lain. Pendekatan perbanding dalam penelitian ini dengan mengkaji dan mengkritisi peraturan prosedur arbitrase pada negara maju di Asia serta konvensikonvensi internasional yang dijadikan pedoman dalam penyusunan Undang Undang Arbitrase di Indonesia.

\footnotetext{
4 Sefriani, (2012), Pelaksanaan Putusan Arbitrase Komersial Internasional Terkait Imunitas Aset Negara, Disertasi, Program Pasca Sarjana Ilmu Hukum Universitas Gadjah Mada, Yogyakarta. 5Triyana, Djunyanto, (2016), Arbitrase Online Sebagai Metode Penyelesaian Sengketa Kredit Bermasalah Dihubungan Dengan Prinsip Itikad Baik Dalam Rangka Mendukung Perbankan Yang Sehat, Disertasi, Program Pasca Sarjana Ilmu Hukum Universitas Padjajaran, Bandung.
} 


\section{Hasil Dan Pembahasan}

\subsection{Keunggulan Konsep Beracara Secara E-Arbitration}

Menurut Wyasa Putra, penyelesaian sengketa bisnis melalui arbitrase disarankan digunakan hanya pada kasus-kasus sengketa tertentu yaitu: (i) hanya jika tingkat ketegangan (level of tension) diantara pihak-pihak yang bersengketa masih rendah, (ii) hanya jika para pihak memiliki positive intention untuk menyelesaikan sengketa dengan menggunakan procedure arbitrase dan (iii) hanya jika ada mandatory clause dalam perjanjian diantara para pihak bahwa jika timbul sengketa diantara mereka maka mereka akan menggunakan arbitrase sebagai prosedur penyelesaian sengketa. ${ }^{6}$

Obyek pikiran harus bersifat nyata atau berbentuk fakta. Konsep dari sistem berpekara secara online ialah sebagai rangkaian proses berperkara dengan kombinasi online dan beracara biasa, administrasi online terbatas hanya pada penyampaian dokumen gugatan/permohonan, jawaban, replik, duplik dan kesimpulan sedangkan pemeriksaan bukti dan saksi tetap dilakukan dengan kehadiran para pihak di lingkungan peradilan terkait.

Arbitrase sebagai cara penyelesaian sengketa hukum di luar proses pengadilan bukan sesuatu hal yang baru dalam sistem penyelesaian sengketa di Indonesia maupun internasional. Arbitrase lebih diminati jika dibandingkan dengan peradilan umum, "It is not difficult to understand why parties seeking to settle contractual disputes rely on international arbitration. Arbitration proceedings can be highly favorable compared to the rigidity and complexity of litigating in national" courts. ${ }^{7}$ Although arbitration has been successful in resolving commercial and other contract disputes, this does not assure success in other areas, such as wills or trusts. ${ }^{8}$ Bahwa tidak semua sengketa yang dapat diselesaikan melalui arbitrase meskipun arbitrase telah berhasil mengatasi masalah komersial dan sengketa kontrak lainnya, hal ini tidak menjamin keberhasilannya di area lain, seperti wasiat atau trusts. Menurut Burch, mandatory arbitration is a recent phenomenon, and it poses a seemingly intractable problem. After the Supreme Court's Southland Corp. v. Keating decision in 1984, companies increasingly began adding arbitration provisions to their consumer, employee, and franchisee agreements-often using those provisions to restrict or eliminate the nondrafting parties rights. ${ }^{9}$ Disebutkan bahwa mandat arbitrase adalah fenomena baru, dan itu tampaknya masalah yang sulit untuk dipecahkan. Setelah Putusan Mahkamah Agung Southland Corp V. Keating pada tahun 1984, perusahaan semakin banyak yang menambahkan ketentuan arbitrase ke dalam kesepakatan konsumen, karyawan, dan franchisee mereka sering kali menggunakan ketentuan ini untuk membatasi atau menghilangkan hak-hak pihak-pihak yang tidak tertulis.

Suatu bentuk penyelesaian sengketa alternatif, seperti arbitrase yang mengikat, memberikan manfaat sosial yang lebih besar daripada litigasi, dinamika dari sebuah

\footnotetext{
${ }^{6}$ Wyasa P.I.B, (2013), Alternative Dispute Resolution, Bahan Kuliah Hukum Bisnis Internasional Pada Program Sarjana Hukum Fakultas Hukum Universitas Udayana, Denpasar, h. 21.

7 Bucy, D.R, (2010), How To Best Protect Party Rights The Future of Interim Relief in International Commercial Arbitration Under The Amended Uncitral Model Law, www.HeinOnline.org, p. 583.

${ }^{8}$ Katzen,E, (2011), Arbitration Clauses in Will and Trusts; Defining the Parameters for Mandatory

Arbitration of Wills and Trusts, Vol. 24, www.heinonline.com, p.120.

${ }_{9}^{9}$ Burch,T.V, (2011), Regulating Mandatory Arbitration, Vol. 04, www.heinoline.com, p. 1309.
} 
proses harus cenderung mendorong para pihak untuk memasukkan klausul yang menyerahkan sengketa di kemudian hari ke lembaga arbitrase. Mandatory arbitration offers the potential for a faster and less costly means of dispute resolution. It holds out the promise of a process that is more efficient and accessible for plaintiffs, yet still preferable for businesses. 10 Mandatory arbitrase menawarkan cara yang berpotensi lebih cepat dan lebih murah sebagai resolusi sengketa. Ini mengulurkan janji dari sebuah proses yang lebih efisien dan dapat diakses oleh para penggugat, namun masih lebih disukai untuk bisnis.

Posner berpendapat jika hukum itu lebih diketahui maka akan lebih mudah mengkaji implikasi perkembangannya. Terkait dengan kajian tersebut Posner mengembangkan Hukum dan Ekonomi melalui bukunya The Economics of Justice (1981). Secara harfiah" konsep efisiensi selalu dikaitkan dengan pengertian penghematan yang terkait dengan penilaian ekonomis dari suatu barang dan jasa". ${ }^{11}$ Sebuah penelitian yang dikaji berdasarkan unsur filosofis sepatutnyalah memenuhi syarat tiga tiang penyangga ilmu tersebut, sehingga diharapkan hasilnya dapat memberikan nilai-nilai yang bermanfaat dan dapat diuji kebenarannya. Ontologi membahas tentang apa yang ingin kita ketahui, seberapa jauh kita ingin tahu, atau dengan perkataan lain suatu pengkajian mengenai teori tentang"ada. ${ }^{12}$ Obyek dari penelitian ini adalah kajian komparatif acara pembuktian $e$-arbitration, kajian acara pembuktian e-arbitration merupakan suatu proses validasi pengetahuan sehingga pengetahuan ini akan memberikan manfaat dari keunggulan metode ini di masyarakat. Manfaat yang akan ditemukan dalam kajian ini berupa keunggulan dari penerapan konsep beracara dengan e-arbitration. Ketika peraturan hukum itu mampu melancarkan interaksi dan transaksi maka peraturan hukum tersebut efisien. Pemikiran Posner mengenai efisiensi sesuai dengan karakteristik arbitrase yang sering disebut lebih efisien jika dibandingkan penyelesaian sengketa melalui peradilan umum yang panjang dan berbelit-belit. Proses penyelesaian sengketa melalui arbitrase yang bersifat final dan mengikat mendapat perhatian besar dari pengusaha Indonesia dalam memilih penyelesaian sengketa antara para pihak.

\subsection{Perbandingan Hukum Acara Pembuktian E-Arbitration di Indonesia dengan di Cina.}

Pembuktian merupakan cara untuk menunjukkan kejelasan perkara kepada hakim supaya dapat dinilai apakah masalah yang dialami penggugat atau korban dapat ditindak secara hukum. ${ }^{13}$ Prosedur pembuktian dalam hukum acara perdata sangat penting sebagai dasar pertimbangan hakim untuk membuat putusan terhadap perkara yang sedang ditangani. Dalam Pasal 1 angka 5 Perma Nomor 3 Tahun 2018 menyebutkan"serangkaian proses penerimaan gugatan/permohonan, jawaban, replik, duplik dan kesimpulan, pengelolaan, penyampaian dan penyimpanan dokumen perkara perdata/agama/tata usaha militer/tata usaha negara dengan menggunakan sistem elektronik yang berlaku di masing-masing lingkungan" peradilan. ${ }^{14}$ Konsep dari sistem berperkara secara online ialah sebagai rangkaian proses berperkara dengan

\footnotetext{
${ }^{10}$ Miles B. Farmer, 2012, Mandatory and Fair - A Better System of Mandatory Arbitration, www.heinonline.com, p. 2348.

${ }^{11}$ Sugianto, F, (2014), Economic Analy sis of Law, Kencana, Jakarta p.26

${ }^{12}$ Sumantri, J.S, (2015), Ilmu Dalam Perspektif, Yayas an Pustaka Obor Indonesia, Jakarta, p.5

${ }^{13}$ Asikin,Z (2015), Hukum Acara Perdata di Indonesia, Kencana, Jakarta, p.98

14 Peraturan Mahkamah Agung Republik Indonesia Nomor 3 Tahun 2018 tentang administrasi perkara pengadilan secara elektronik
} 
kombinasi online dan beracara biasa, administrasi online terbatas hanya pada penyampaian dokumen gugatan/permohonan, jawaban, replik, duplik dan kesimpulan sedangkan pemeriksaan bukti dan saksi tetap dilakukan dengan kehadiran para pihak di lingkungan peradilan terkait. Dalam Pasal 24 Butir 2 Peraturan dan Prosedur Badan Arbitrase Nasional Indonesia (BANI) disebutkan ringkasan"bukti-bukti Majelis Arbitrase atau Arbiter Tunggal dapat, apabila dianggap perlu, meminta para pihak untuk memberikan penjelasan atau mengajukan dokumendokumen yang dianggap perlu dan/atau untuk menyampaikan ringkasan seluruh dokumen dan bukti lain yang telah dan/atau akan diajukan oleh pihak tersebut guna mendukung fakta-fakta dalam Surat Permohonan Tuntutan atau Surat Jawaban, dalam jangka waktu yang ditetapkan oleh Majelis Arbitrase atau" Arbiter Tunggal. ${ }^{15}$ BANI belum mengatur ketentuan pemeriksaan pembuktian secara online.

Article 12 Collection of Evidence, Shenzhen Court International Online Arbitration Rules (selanjutnya disebut SCIA Online Arbitration Rules) menyebutkan: Any electronic version of the identity document, duplicate business license, letter of authorization, identity document of legal representative, and other certification materials, as well as any electronic version of documentary evidence, expert opinion, record of on-site investigation, and other evidentiary materials submitted by a party, after passing the review of the arbitral tribunal, shall be deemed as an original document for purposes of formality requirement. If the other party objects to the authenticity of any of the foregoing materials with due cause, the arbitral tribunal may require the party to provide the original document. ${ }^{16}$ E-arbitration Shenzhen, Cina telah mengatur mengenai acara pemeriksaan pembuktian arbitrase secara online, juga disebutkan jika suatu pihak berkeberatan terhadap keaslian dokumen dalam pembuktian dengan alasan yang wajar maka majelis arbiter dapat meminta pihak tersebut untuk memberikan dokumen yang dimaksud. Virtual"courts, online courts and advance online dispute resolution (ODR) deliver a much speedier resolution, quicker even than the resonable time within which justice requires that a case should be heard, then this may well offset the dissapointment of not being vindicated in"person. 17 Richard Susskind menyebutkan jika para pihak membutuhkan pembenaran publik dalam perkaranya kemungkinan tidak selaras dengan efisiensi dari sistem e-court, sehingga tidak semua kalangan masyarakat sepakat dengan manfaat dari pemeriksaan perkara dengan online.

Prinsip pembuktian yang dianut hukum acara perdata adalah apa yang disebut dengan istilah beyond reasonable doubt. Kebenaran yang diwujudkan benar-benar berdasarkan bukti-bukti yang tidak meragukan sehingga kebenaran itu dianggap bernilai sebagai kebenaran hakiki. ${ }^{18}$ Berpedoman dengan prinsip ini, metode pemeriksaan pembuktian secara online adalah tanpa melihat, menyentuh, mendengar secara nyata dan langsung alat-alat dan dokumen pembuktian oleh majelis arbiter maka pembuktian tidak sesuai dengan prinsip-prinsip pembuktian sebagai kebenaran yang hakiki.

\footnotetext{
${ }^{15}$ Peraturan dan Prosedur Badan Arbitrase Nasional Indonesia (BANI)

16 Shenzhen Court International Online Arbitration Rules

${ }^{17}$ Susskind, Op.Cit, p. 118.

${ }^{18}$ Asikin, Op.Cit, p. 99
} 


\section{Kesimpulan}

Peralihan arbitrase tradisional menjadi e-arbitration memberikan perubahan berupa keunggulan yang cukup signifikan, diantaranya: proses berperkara lebih cepat, biaya panjar perkara lebih murah, lebih efisien bagi proses penyelesaian sengketa komersial lintas batas negara, dokumentasi berkas lebih tersistem dan terorganisir sehingga sesuai dengan prinsip peradilan yang sederhana, cepat dan biaya ringan. Prosedur pembuktian e-arbitration belum diatur oleh BANI tapi telah diatur oleh negara di Asia yaitu Cina, Shenzhen (SCIA online arbitration rules). Bahwa E-arbitration Shenzhen, Cina telah mengatur mengenai acara pemeriksaan pembuktian arbitrase secara online, juga disebutkan jika suatu pihak berkeberatan terhadap keaslian dokumen dalam pembuktian dengan alasan yang wajar maka majelis arbiter dapat meminta pihak tersebut untuk memberikan dokumen yang dimaksud. Prosedur pembuktian online menurut hemat penulis tidak sesuai dengan prinsip pembuktian yang dianut oleh hukum acara perdata di Indonesia yaitu kebenaran yang diwujudkan berdasarkan bukti-bukti yang tidak meragukan sebagai kebenaran formil.

\section{Daftar Pustaka / Daftar Referensi}

\section{Buku}

Asikin, Zainal, (2015), Hukum Acara Perdata di Indonesia, Kencana, Jakarta.

Putra, I.B.W, (2013), Filsafat Ilmu: Filsafat Ilmu Hukum, Udayana University Press, Denpasar,

Richard Susskind, (2017), Tomorrow's Lawyers: An Introduction to Your Future, Oxford University Press, Great Britain,

Sugianto, F. (2014), Economic Analysis of Law, Kencana, Jakarta,

Suriasumantri, J.S. (2015), Ilmu Dalam Perspektif, Yayasan Pustaka Obor Indonesia, Jakarta,

\section{Jurnal}

Bucy, D.R, (2010), How To Best Protect Party Rights The Future of Interim Relief in International Commercial Arbitration Under The Amended Uncitral Model Law, www.HeinOnline.org

Burch, T.V, (2011), Regulating Mandatory Arbitration,Vol. 04, www.heinoline.com,

Elliman, T, Eatock, J, (2005), Onlinessupport For Arbitration: Designing Software For A Flexible Business Process, Int. J. Information Technology and Management, Vol. 4, No. 4, https://www.researchgate.net/profile/Julie_Eatock/publication/220490527_Online_s upport_for_arbitration_Designing_software_for_a_flexible_business_process/links/56 eaa2ae08ae8c97677b85af

Gibbons, L.J., (2000), Private Law, Public "Justice": Another Look at Privacy, Arbitration, and Global E-Commerce, Ohio State Journal On Dispute Resolution, Vol 15:3, https://kb.osu.edu/bitstream/handle/1811/80009/1/OSJDR_V15N3_769.pdf 
Katzen, E, (2011), Arbitration Clauses in Will and Trusts; Defining the Parameters for Mandatory Arbitration of Wills and Trusts, Vol. 24, www.heinonline.com,

Knapp, C.L, (2009), Blowing The Whistle on Mandatory Arbitration: Unconscionabillity as a Signaling Device, Vol. 46, www.heinonline.com

Miles B. Farmer, (2012), Mandatory and Fair - A Better System of Mandatory Arbitration, www.heinonline.com,

\section{Disertasi}

Sefriani, (2012), Pelaksanaan Putusan Arbitrase Komersial Internasional Terkait Imunitas Aset Negara, Disertasi, Program Pasca Sarjana Ilmu Hukum Universitas Gadjah Mada, Yogyakarta.

Triyana, D, (2016), Arbitrase Online Sebagai Metode Penyelesaian Sengketa Kredit Bermasalah Dihubungan Dengan Prinsip Itikad Baik Dalam Rangka Mendukung Perbankan Yang Sehat, Disertasi, Program Pasca Sarjana Ilmu Hukum Universitas Padjajaran, Bandung.

\section{Peraturan dan Perundang-undangan}

Peraturan Mahkamah Agung Republik Indonesia Nomor 3 Tahun 2018 tentang Administrasi Perkara Pengadilan Secara Elektronik

BANI Arbitration Procedures

Shenzhen Court International Online Arbitration Rules 